\title{
APLIKASI STABILISASI RICE BRAN DALAM FOOD BAR BERBASIS TEPUNG SORGUM SEBAGAI PANGAN DARURAT
}

Application of Stabilized Rice Bran in Food Bar based on Sorghum Flour as an Emergency Food

\author{
Lufi Karisma Rahmawati ${ }^{1)}$, Karseno ${ }^{1)}$, Nur Aini ${ }^{1) *}$ \\ ${ }^{1)}$ Program Studi Teknologi Pangan, Fakultas Pertanian, Universitas Jenderal Soedirman \\ Jalan Dr. Soeparno No. 73, Purwokerto, 53122 \\ *Korespondensi Penulis: nur.aini@unsoed.ac.id
}

\begin{abstract}
Indonesia is a country that is prone to natural disasters. In emergency situation, a special food design for disaster victims that is practical and nutritional is needed. Food bar is one example of practical food that is suitable for consumption in emergencies. The basic ingredients of food bars can be made from sorghum flour which is rich in nutritional value. So that its function as an emergency food is more optimal then a food bar is applied using a stabilized rice bran. The purpose of this research was to determine the process condition of rice bran stabilization to produce rice bran with good taste and aroma, the organoleptic character of food bars and the physical and chemical characteristics of the five best food bar products. The method used is an experimental method with RBD (Randomized Group Design). The factors studied consisted of two factors: the use of roasted temperatures $(T)$ and food bar formulations $(P)$. The results obtained were stable rice bran with the use of a temperature of $120^{\circ} \mathrm{C}$ and a stabilization time of 6 minutes, which will later be used in the process of making food bars. The best food bar product formulation was food bar with the ratio of sorghum flour and rice bran stabilizing flour as much as $85 \%: 15 \%$ (P4) which was baked at $130^{\circ} \mathrm{C}$ (T4). This formulation showed a total protein value of $14.99 \%, 30.08 \%$ fat, $40.27 \%$ carbohydrate and 246.01 kcal energy and has physical characteristics in the form of a hardness value of $1597.56 \mathrm{~g}$ force.
\end{abstract}

Keywords: food bar, sorghum flour, stabilized rice bran

\section{PENDAHULUAN}

Indonesia merupakan negara yang rawan terhadap bencana. Indonesia menempati urutan ketiga di dunia sebagai negara rawan bencana setelah India dan China (BNPB, 2013). Dalam kondisi yang serba darurat, salah satu bantuan yang sangat dibutuhkan korban bencana adalah makanan. Pada keadaan seperti ini diperlukan desain pangan khusus untuk keadaan darurat bencana yang dapat langsung dikonsumsi (ready to eat), praktis untuk didistribusikan, dan bergizi. Salah satu alternatif pangan yang diberikan pada para pengungsi adalah pangan darurat (Aini et al., 2018)

Pangan darurat adalah makanan yang memiliki energi dan densitas zat gizi yang tinggi untuk korban bencana alam yang dapat dikonsumsi segera pada keadaan darurat. Terdapat lima karakter dari pangan darurat, yaitu aman, rasa dapat diterima, mudah dibagikan, mudah digunakan, dan memiliki zat gizi lengkap.

Salah satu contoh produk pangan darurat yang memiliki umur simpan yang cukup lama adalah food bar. Food bar merupakan salah satu produk pangan olahan kering berbentuk batang, persegi yang memiliki nilai $\mathrm{a}_{\mathrm{w}}$ rendah (Aini et al., 2018). Saat ini kebanyakan bahan pangan yang dijadikan dalam pembuatan food bar dibuat dari serealia seperti gandum, jagung, dan beras. Padahal food bar dapat juga dibuat dari tumbuhan serealia lainnya salah satunya yaitu sorgum.

Sorgum (Sorghum bicolor L. Moench) merupakan serealia sumber karbohidrat. Nilai gizi sorgum cukup memadai sebagai bahan pangan, yaitu 
mengandung sekitar $83 \%$ karbohidrat, $3,50 \%$ lemak, dan $10 \%$ protein (basis kering). Ahza (1988) menyatakan bahwa tepung sorgum memiliki potensi untuk dikembangkan menjadi produk pangan, salah satu yang sangat potensial yaitu produk food bar. Tepung rice bran dapat diaplikasikan untuk meningkatkan nilai gizi food bar, serta agar kualitas food bar secara keseluruhan lebih bagus apabila digunakan sebagai produk pangan darurat.

Rice bran atau bekatul adalah hasil samping dari penggilingan padi yang sebenarnya merupakan selaput inti biji padi. Rice bran mengandung sejumlah senyawa fenolik, serta kaya akan 25,3 g serat pangan; 5,39 g vitamin B kompleks; dan 8,3 g mineral (per $100 \mathrm{~g}$ ). Selama proses pengolahan perlu dijaga kualitas rice bran agar tidak menurun. Penurunan kualitas rice bran disebabkan oleh aktivitas enzim lipase yang menyebabkan terbentuknya aroma tengik atau rancid yang dapat menurunkan penerimaan konsumen (Liu et al., 2017).

Stabilisasi rice bran perlu dilakukan untuk menginaktifkan enzim lipase dan dihasilkan rice bran dengan aroma dan flavor yang disukai (Rafe \& Sadeghian, 2017). Berdasarkan nutrisi yang dimiliki dari kedua bahan pangan tersebut dapat dijadikan rujukan untuk mendukung pengembangan produk pangan darurat. Menurut Liu (2017) pangan yang diinginkan tidak hanya bernilai gizi tinggi, akan tetapi juga harus memenuhi tiga fungsi dasar yaitu sensory (penampilannya yang menarik dan cita rasa yang enak), nutritional (bernilai gizi tinggi), dan physiological (memberikan pengaruh fisiologis yang menguntungkan bagi tubuh) sehingga diperlukan penelitian mengenai formulasi tepung sorgum dan tepung stabilisasi rice bran untuk pengembangan produk food bar sebagai pangan darurat.

Proporsi antara tepung sorgum dan rice bran menentukan karakter sensori food bar. Menurut Trisnawati et al. (2019), produk bakery yang menggunakan rice bran memiliki aroma kurang disukai sehingga perlu ditentukan komposisi bahan yang tepat.

Suhu pemanggangan merupakan salah satu faktor yang menentukan sifat sensori food bar secara keseluruhan (warna, tekstur, aroma dan flavor) karena penggunaan suhu yang cukup tinggi akan memunculkan senyawa-senyawa baru hasil reaksi maillard yang sangat berkontribusi pada pembentukan flavor baru (Agbaje et al., 2014). Menurut da Silva (2014), komposisi bahan yang berbeda memerlukan waktu pemanggangan yang berbeda. Oleh karena itu, pada pembuatan food bar dari tepung sorgum dan stabilized rice bran perlu ditentukan waktu pemanggangan yang tepat.

Tujuan dari penelitian ini adalah untuk mengetahui proses stabilisasi rice bran yang tepat sehingga rancidity produk yang dihasilkan minimal untuk diaplikasikan pada pembuatan food bar, dan mengetahui karakter organoleptik food bar. Selain itu juga untuk mengetahui karakter fisik dan kimia lima produk terbaik food bar berbasis tepung sorgum dengan aplikasi stabilized rice bran.

\section{METODE PENELITIAN}

\section{Alat dan Bahan}

Alat-alat yang digunakan dalam penelitian meliputi timbangan analitik, ayakan 80 mesh, loyang, baskom plastik, spatula, cetakan, oven, kompor, texture analyser (Brookfield Texture CT3 LFRA), tanur, oven (Memert 854 Schwabach, Germany), desikator, labu kjeidahl, soxhlet, lemari asam, spektofotometer (Shimadzu $U V-1800$ ), labu ukur, buret, filler, gelas ukur, penangas air, pipet, erlenmeyer, dan kertas saring. Bahan-bahan yang digunakan dalam penelitian ini terdiri dari: tepung sorgum merah (merk Hasil Bumiku), stabilized rice bran (diperoleh dari penggilingan padi Tambak Sogra), garam, susu skim, vanili, baking powder, tepung tapioka (merk rose brand), margarin (merk 
blue band), gula halus, madu asli merk madu TJ, telur, air (diperoleh dari Toko Intisari), larutan garam 5\%, aquades, $\mathrm{Na}_{2} \mathrm{SO}_{4}, \mathrm{CuSO}_{4}$, selenium, indikator $\mathrm{Mr}-$ BCG, $\mathrm{H}_{2} \mathrm{SO}_{4}$ pekat, $\mathrm{H}_{3} \mathrm{BO}_{3} 4 \%, \mathrm{HCl} 0,02$ $\mathrm{N}, \mathrm{NaOH} 40 \%, \mathrm{Na}_{2} \mathrm{~S}_{2} \mathrm{O}_{3} 5 \%$, etanol, $\mathrm{DPPH}$, enzim alpha amylase, enzim beta amylase dan enzim pepsin.

\section{Tahapan Penelitian}

Proses Pembuatan Stabilized Rice Bran

Pembuatan stabilized rice bran yang nantinya akan diaplikasikan pada adonan food bar berbasis tepung sorgum. Pertama, yaitu mengayak rice bran dengan ayakan 80 mesh untuk membersihkan sisa-sisa kotoran. Kemudian rice bran diletakkan dan diratakan di atas loyang, lalu dioven dengan suhu $120^{\circ} \mathrm{C}$ selama 6 menit.

\section{Proses Pembuatan Food Bar}

Tahap pertama dalam pembuatan food bar adalah pencampuran bahan kering yaitu campuran tepung sorgum dan tepung stabilized rice bran jumlah sesuai perlakuan (tepung terigu $10 \mathrm{~g}$, gula halus 30 $\mathrm{g}$, susu skim $20 \mathrm{~g}$ dan vanili $2 \mathrm{~g}$ ) sampai homogen. Selanjutnya, ditambahkan bahan-bahan cair (madu $20 \mathrm{~g}$, margarin 20 $\mathrm{g}$, kuning telur $15 \mathrm{~g}$, minyak kelapa $30 \mathrm{~g}$ dan air $60 \mathrm{~g}$ ) ke dalam adonan, dan adonan diuleni sampai kalis. Tahap berikutnya adonan yang sudah kalis dicetak di dalam loyang persegi berukuran $24 \times 24 \mathrm{~cm}$. Terakhir, adonan food bar dioven selama 20 menit dengan variasi suhu $115^{\circ} \mathrm{C}$, $120^{\circ} \mathrm{C}, 125^{\circ} \mathrm{C}$, dan $130^{\circ} \mathrm{C}$. Food bar yang dihasilkan berukuran $10 \times 2,5 \times 1,5 \mathrm{~cm}$.

\section{Rancangan Percobaan}

Penelitian ini merupakan jenis penelitian eksperimental menggunakan rancangan acak kelompok sebagai rancangan percobaan. Faktor yang diteliti terdiri dari 2 yaitu suhu pemanggangan $(\mathrm{T})$ terdiri dari 3 taraf yaitu $\mathrm{T} 1=115^{\circ} \mathrm{C}, \mathrm{T} 2=$ $120^{\circ} \mathrm{C}, \quad \mathrm{T} 3=125^{\circ} \mathrm{C}, \quad \mathrm{T} 4=130^{\circ} \mathrm{C}$ dan perbandingan proporsi antara tepung sorgum dan stabilized rice bran $(\mathrm{P})$ yang terdiri 3 taraf yaitu P1 (55:45), P2 (65:35), P3 (75:25) dan P4 (85:15). Komposisi bahan yang lain meliputi tepung terigu 10 $\mathrm{g}$, gula halus $30 \mathrm{~g}$, susu skim $20 \mathrm{~g}$ dan vanili $2 \mathrm{~g}$, madu $20 \mathrm{~g}$, margarin $20 \mathrm{~g}$, kuning telur $15 \mathrm{~g}$, minyak kelapa $30 \mathrm{~g}$, dan air $60 \mathrm{~g}$.

Data analisis sensoris dengan menggunakan metode skoring, kemudian dianalisis statistik dengan uji Friedman lalu dilanjutkan uji indeks efektivitas untuk menentukan lima produk terbaik. Lima produk terbaik kemudian dianalisis kimia dengan menggunakan uji one way ANOVA. Apabila data menunjukkan perbedaan yang signifikan maka dilanjutkan dengan uji beda nyata menggunakan analisis Duncan's Multiple Range Test (DMRT) pada taraf signifikan $\alpha$ $=0,05$.

\section{Metode Analisis}

Produk food bar dianalisis kadar protein (Sumantri, 2013); kadar lemak (Sudarmadji, 2007), dan kadar karbohidrat. Analisis sifat fisik dilakukan dengan uji kekerasan (hardness). Produk food bar diujikan secara organoleptik metode skoring kepada 25 panelis semi terlatih dengan nilai 1-5.

\section{HASIL DAN PEMBAHASAN}

\section{Karakteristik Organoleptik Food Bar}

Hasil analisis Friedman pengaruh kombinasi perlakuan terhadap variabel sensori produk food bar disajikan pada Tabel 1. Sensori menunjukkan karakteristik warna, aroma, tekstur, flavor dan kesukaan panelis terhadap food bar.

\section{Warna Food Bar}

Hasil analisis Friedman menunjukkan bahwa kombinasi perlakuan suhu pemanggangan dan formulasi food bar (TP) berpengaruh nyata terhadap warna food bar yang dihasilkan. Warna food bar pada kombinasi perlakuan ditunjukkan pada Tabel 1. 
Tabel 1. Respon panelis terhadap nilai organoleptik berbagai kombinasi perlakuan food bar

\begin{tabular}{|c|c|c|c|c|c|}
\hline Data & Warna & Tekstur & $\begin{array}{c}\text { Aroma rice } \\
\text { bran }\end{array}$ & Flavor & Kesukaan \\
\hline \multicolumn{6}{|c|}{ Rata-rata perlakuan } \\
\hline $\mathrm{T} 1 \mathrm{P} 1$ & $2,14 \mathrm{de}$ & 3,28 cdef & $3,08 \mathrm{bc}$ & $2,56 \mathrm{bc}$ & $2,54 \mathrm{bc}$ \\
\hline $\mathrm{T} 1 \mathrm{P} 2$ & $4,34 \mathrm{a}$ & $2,26 \mathrm{~g}$ & $3,70 \mathrm{a}$ & $3,58 \mathrm{a}$ & $3,70 \mathrm{a}$ \\
\hline T1P3 & $3,60 \mathrm{ab}$ & $2,58 \mathrm{fg}$ & $3,18 \mathrm{abc}$ & $3,04 \mathrm{abc}$ & $2,94 \mathrm{abc}$ \\
\hline $\mathrm{T} 1 \mathrm{P} 4$ & $2,94 \mathrm{bcd}$ & $2,84 \mathrm{efg}$ & $3,36 \mathrm{abc}$ & $3,06 \mathrm{abc}$ & $2,94 \mathrm{abc}$ \\
\hline $\mathrm{T} 2 \mathrm{P} 1$ & $3,26 \mathrm{abc}$ & $3,02 \mathrm{defg}$ & $2,98 \mathrm{bc}$ & $2,60 \mathrm{bc}$ & $2,56 \mathrm{bc}$ \\
\hline $\mathrm{T} 2 \mathrm{P} 2$ & $2,90 \mathrm{bcd}$ & $3,60 \mathrm{abcd}$ & $3,20 \mathrm{abc}$ & $2,74 \mathrm{bc}$ & $2,76 \mathrm{abc}$ \\
\hline $\mathrm{T} 2 \mathrm{P} 3$ & $2,96 \mathrm{bc}$ & 3,44 bcde & $3,64 \mathrm{ab}$ & $3,18 \mathrm{ab}$ & $3,08 \mathrm{abc}$ \\
\hline $\mathrm{T} 2 \mathrm{P} 4$ & $2,10 \mathrm{e}$ & 3,44 bcde & $3,30 \mathrm{abc}$ & $2,42 \mathrm{c}$ & $2,34 \mathrm{c}$ \\
\hline T3P1 & 2,82 bcde & $3,82 \mathrm{abc}$ & $2,86 \mathrm{c}$ & $2,72 \mathrm{bc}$ & $2,50 \mathrm{bc}$ \\
\hline $\mathrm{T} 3 \mathrm{P} 2$ & 2,78 cde & 3,48 bcde & $3,38 \mathrm{abc}$ & $3,22 \mathrm{ab}$ & $3,10 \mathrm{ab}$ \\
\hline T3P3 & $2,80 \mathrm{cde}$ & $3,02 \mathrm{defg}$ & $3,14 \mathrm{abc}$ & $2,82 \mathrm{abc}$ & $2,88 \mathrm{abc}$ \\
\hline T3P4 & 2,82 bcde & $4,02 \mathrm{ab}$ & $3,24 \mathrm{abc}$ & $2,44 \mathrm{c}$ & $2,44 \mathrm{bc}$ \\
\hline T4P1 & $2,82 \mathrm{cde}$ & $3,82 \mathrm{abc}$ & $3,34 \mathrm{abc}$ & $2,72 \mathrm{bc}$ & $2,64 \mathrm{bc}$ \\
\hline $\mathrm{T} 4 \mathrm{P} 2$ & $2,98 \mathrm{bc}$ & $3,64 \mathrm{abcd}$ & $3,30 \mathrm{abc}$ & $2,86 \mathrm{abc}$ & $2,60 \mathrm{bc}$ \\
\hline T4P3 & $3,40 \mathrm{abc}$ & 3,44 bcde & $3,40 \mathrm{abc}$ & $2,96 \mathrm{abc}$ & $2,66 \mathrm{bc}$ \\
\hline $\mathrm{T} 4 \mathrm{P} 4$ & $3,40 \mathrm{abc}$ & $4,36 \mathrm{a}$ & 3,18 abc & $2,82 \mathrm{abc}$ & $2,70 \mathrm{abc}$ \\
\hline
\end{tabular}

Keterangan: - $\mathrm{T} 1=$ suhu $115^{\circ} \mathrm{C} ; \mathrm{T} 2=$ suhu $120^{\circ} \mathrm{C} ; \mathrm{T} 3=$ suhu $125^{\circ} \mathrm{C} ; \mathrm{T} 4=$ suhu $130^{\circ} \mathrm{C}$

- $\mathrm{P} 1=55 \%$ tepung sorgum : 45\% stabilized rice bran; $\mathrm{P} 2=65 \%$ tepung sorgum : $35 \%$ stabilized rice bran; $\mathrm{P} 3=75 \%$ tepung sorgum : $25 \%$ stabilized rice bran; $\mathrm{P} 4=85 \%$ tepung sorgum : $15 \%$ stabilized rice bran

- Angka yang diikuti huruf yang sama menunjukkan tidak ada perbedaan nyata pada uji Friedman dengan taraf $\alpha=5 \%$

Warna food bar yang dihasilkan berdasarkan respon panelis, yang memiliki nilai paling rendah yaitu 2,1 yang berarti sedikit terang pada perlakuan T2P4 sedangkan nilai yang paling tinggi yaitu 4,34 yang berarti gelap pada food bar perlakuan T1P2. Warna food bar yang dihasilkan hanya memiliki satu jenis warna yaitu coklat. Persamaan warna terjadi karena adanya proses pemanggangan. Hasilnya, pangan olahan kehilangan warna dan dapat menurunkan nilai sensoris (Mulyadi et al., 2014). Selain itu, warna yang dihasilkan berasal dari perpaduan warna tepung yang digunakan. Tepung sorgum merah cenderung berwarna merah muda kecoklatan sedangkan pada tepung stabilized rice bran berwarna kuning kecoklatan.

\section{Tekstur Food Bar}

Hasil analisis Friedman menunjukkan bahwa kombinasi perlakuan suhu pemanggangan dan formulasi food bar (TP) berpengaruh nyata terhadap tekstur food bar yang dihasilkan. Tekstur food bar pada kombinasi perlakuan disajikan pada Tabel 1. Tekstur food bar yang dihasilkan berdasarkan respon panelis, yang memiliki nilai paling rendah yaitu 2,26 yang berarti memiliki tekstur sedikit padat pada perlakuan T1P2. Nilai yang paling tinggi yaitu 4,36 yang berarti memiliki tekstur padat pada food bar perlakuan T4P4.

Tekstur food bar dapat dipengaruhi oleh bahan dasar, ketebalan cetakan dan suhu oven yang terlalu tinggi. Food bar yang memiliki proporsi tepung rice bran lebih banyak cenderung memiliki tekstur 
yang lebih mudah hancur. Hal ini dikarenakan rice bran memiliki kandungan serat lebih tinggi (Astawan et al., 2013) Menurut penelitian Kusumastuty et al. (2015) dalam pembuatan food bar sebagai pangan darurat berbasis tepung jagung dan tepung rice bran, tekstur yang dihasilkan tergantung kepada proporsi bahan yang digunakan. Food bar dengan tepung jagung yang lebih dominan akan membuat tekstur food bar menjadi lebih keras, sedangkan apabila food bar dengan tepung rice bran yang lebih dominan akan membuat tekstur food bar menjadi mudah hancur karena kandungan seratnya lebih tinggi. Selain itu, hal yang dapat mempengaruhi tekstur adalah energi panas yang akan menyebabkan ikatan hidrogen terputus dan air masuk ke dalam granula pati. Air yang masuk selanjutnya membentuk ikatan hidrogen dengan amilosa dan amilopektin. Proses meresapnya air ke dalam granula menimbulkan ukuran granula meningkat sampai batas tertentu sebelum akhirnya granula tersebut pecah. Gel pati akan mengalami dehidrasi sehingga gel membentuk kerangka yang kokoh.

\section{Aroma Food Bar}

Hasil analisis Friedman menunjukkan bahwa kombinasi perlakuan suhu pemanggangan dan formulasi food bar (TP) berpengaruh nyata terhadap aroma khas rice bran yang ada pada food bar yang dihasilkan. Aroma rice bran pada kombinasi perlakuan disajikan pada Tabel 1.

Aroma rice bran yang dihasilkan berdasarkan respon panelis, yang memiliki nilai paling rendah yaitu 2,86 yang berarti masih memiliki aroma agak khas rice bran pada food bar perlakuan T3P1 sedangkan nilai yang paling tinggi yaitu 3,7 yang berarti memiliki aroma sedikit khas rice bran pada food bar perlakuan T1P2. Aroma rice bran yang terdapat pada food bar tersebut cenderung masih memiliki aroma yang agak khas sampai sedikit khas. Aroma khas bekatul yang terdapat pada food bar disebabkan oleh adanya senyawa tokoferol (komponen volatil) pada rice bran. Pada penelitian Kusumastuty et al. (2015), dari food bar yang dihasilkan memiliki aroma khas rice bran sejalan dengan tingginya tepung rice bran yang digunakan maka aroma rice bran dalam foor bar akan semakin tercium. Oleh karena itu, dalam penelitian Kusumastuty et al. (2015) tepung jagung dan kacang tanah digunakan untuk menutupi aroma tepung rice bran yang tidak begitu enak.

\section{Flavor Food Bar}

Hasil analisis Friedman menunjukkan bahwa kombinasi perlakuan suhu pemanggangan dan formulasi food bar (TP) berpengaruh nyata terhadap flavor yang ada pada food bar yang dihasilkan. Flavor pada kombinasi perlakuan disajikan pada Tabel 1.

Flavor food bar yang dihasilkan berdasarkan respon panelis, yang memiliki nilai paling rendah yaitu 2,42 yang berarti memiliki flavor sedikit enak pada perlakuan T2P4 sedangkan nilai yang paling tinggi yaitu 3,58 yang berarti memiliki flavor enak pada food bar perlakuan T1P2. Food bar yang dikatakan enak merupakan perpaduan dari komponen bahan-bahan yang sangat tepat. Flavor pada food bar diperoleh dari bahan-bahan penyusunnya seperti tepung sorgum, tepung rice bran yang telah distabilisasi, serta bahan-bahan lain penyusun food bar. Faktor yang menyebabkan food bar memiliki flavor sedikit enak dikarenakan penggunaan tepung sorgum yang mengandung senyawa tanin, yang menyebabkan rasa sepat pada produk olahan (Budijanto et al., 2017).

\section{Kesukaan Keseluruhan Food Bar}

Hasil analisis Friedman menunjukkan bahwa kombinasi perlakuan suhu pemanggangan dan formulasi food bar (TP) berpengaruh nyata terhadap nilai kesukaan produk food bar secara keseluruhan. Nilai kesukaan pada 
kombinasi perlakuan disajikan pada Tabel 1.

Tingkat kesukaan panelis terhadap food bar berbahan utama tepung sorgum dan tepung stabilized rice bran, yang memiliki nilai paling rendah yaitu 2,34 yang berarti memiliki tingkat kesukaan sedikit suka pada perlakuan T2P4 sedangkan nilai yang paling tinggi yaitu 3,70 yang berarti memiliki tingkat kesukaan suka pada food bar perlakuan T1P2. Tingkat kesukaan pada food bar diperoleh dari bahan-bahan penyusunnya seperti tepung sorgum, tepung rice bran yang telah distabilisasi, serta bahan-bahan lain penyusun food bar. Faktor yang menyebabkan food bar memiliki rasa pahit pada food bar dapat dipengaruhi oleh adanya kandungan proantosianidin (tanin terkondensasi). Proantosianidin terdapat pada biji sorgum yang memiliki pigmen testa dan warna gelap pada perikarp biji sorgum dapat menjadi indikator keberadaan proantosianidin (Rhodes, 2014). Pada food bar yang memiliki tingkat kesukaan sedikit suka dikarenakan tepung sorgum yang digunakan dalam pembuatan food bar tersebut mengandung senyawa proantosianidin (tanin terkondensasi), yang berkontribusi pada rasa pahit pada food bar sehingga tingkat kesukaan yang dihasilkan memiliki nilai yang rendah.

\section{Karakteristik Kimiawi Food Bar Protein Total Food Bar}

Protein merupakan unsur zat yang sangat penting, sehingga hampir pada seluruh produk pangan jumlahnya selalu disyaratkan. Pada sistem metabolisme protein memiliki fungsi yaitu sebagai unsur pembangun tubuh (Sari et al., 2017). Kombinasi perlakuan suhu pemanggangan dan formulasi food bar (TP) berpengaruh nyata terhadap kadar protein food bar yang dihasilkan. Data yang dihasilkan menunjukkan perbedaan yang signifikan maka dilanjutkan dengan uji beda nyata menggunakan analisis Duncan's Mutliple Range Test (DMRT) pada taraf signifikan $\alpha$
$=0,05$. Nilai kadar protein pada masingmasing sampel food bar menunjukkan nilai tertinggi yang dihasilkan sebesar 15,81\% dan terendah $14,97 \%$ (Gambar 1).

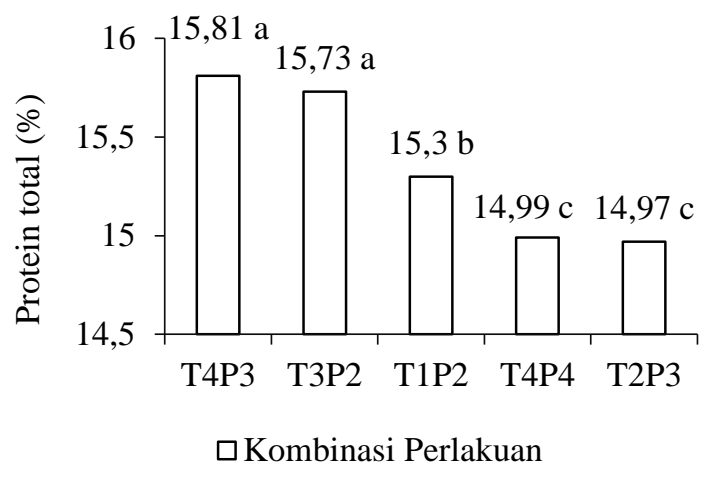

Gambar 1. Nilai protein total food bar dengan perlakuan berbasis tepung sorgum: stabilized rice bran 55\%:45\% ( $\left.\mathrm{P}_{1}\right)$, 65\%:35\% $\quad\left(\mathrm{P}_{2}\right), \quad 75 \%: 25 \% \quad\left(\mathrm{P}_{3}\right)$, $85 \%: 15 \% \quad\left(\mathrm{P}_{4}\right)$ dan variasi suhu pemanggangan $115^{\circ} \mathrm{C} \quad\left(\mathrm{T}_{1}\right), 120^{\circ} \mathrm{C}$ (T2), $125^{\circ} \mathrm{C}(\mathrm{T} 3), 130^{\circ} \mathrm{C}$ (T4)

Tanaman sorgum merupakan tanaman dengan kandungan gizi yang baik. Sorgum memiliki kandungan protein yaitu 11-13\% (Dahir et al., 2015). Hal ini berbeda dengan kandungan zat gizi protein yang dimiliki rice bran Wulandari \& Erma (2010) menyebutkan kandungan protein pada rice bran sebesar 13,11-17,9\% sehingga pengaruh proporsi penambahan stabilized rice bran akan mempengaruhi kandungan protein total dari food bar. Semakin banyak rice bran yang ditambahkan maka kandungan protein akan meningkat. Hal ini dikarenakan rice bran memiliki kandungan lysine yang cukup tinggi (Wulandari \& Erma, 2010).

Protein tertinggi yang dihasilkan pada penelitian lain yaitu food bar sebagai pangan darurat berbasis tepung millet putih dan tepung kacang merah sebesar $12,68 \%$ dengan perbandingan $40 \%$ tepung millet putih dan $60 \%$ tepung kacang merah. Protein terendah yaitu sebesar 12,03\% dengan perbandingan $60 \%$ tepung millet putih dan $40 \%$ tepung kacang merah (Anandito et al., 2016). 
Kualitas food bar yang baik sebagai pangan darurat menurut Zoumas et al. (2002) yaitu kandungan protein yang harus dipenuhi sebesar 14-15\%. Hal ini menunjukkan kandungan protein yang terkandung dalam food bar dengan bahan utama tepung stabilized rice bran dan tepung sorgum sudah memenuhi standar terutama pada T4P4 dan T2P3.

\section{Lemak Food Bar}

Lemak merupakan salah satu kelompok dari lipida. Fungsi lemak pada bahan pangan adalah sebagai salah satu sumber energi tubuh. Kandungan lemak dalam tubuh membantu dalam pelarutan vitamin larut lemak seperti A, D, E, K. selain itu lemak memberikan rasa renyah dan gurih pada bahan pangan (Ekafitri \& Isworo, 2014).

Kombinasi perlakuan suhu pemanggangan dan formulasi food bar (TP) tidak berpengaruh nyata terhadap kadar lemak food bar yang dihasilkan. Data yang dihasilkan menunjukkan tidak ada perbedaan yang signifikan maka data tidak dilanjutkan dengan uji beda nyata menggunakan analisis Duncan's Mutliple Range Test (DMRT) pada taraf signifikan $\alpha$ $=0,05$.

Nilai kadar lemak pada masingmasing sampel food bar menunjukkan nilai tertinggi yang dihasilkan sebesar 30,087\% dan terendah 30,037\% (Gambar 2). Kualitas food bar yang baik sebagai pangan darurat menurut Zoumas (2002), harus memenuhi kandungan lemah sebesar 35$45 \%$. Hal ini menunjukkan kandungan lemak yang terkandung dalam food bar dengan bahan utama tepung stabilized rice bran dan tepung sorgum belum memenuhi standar. Hal tersebut karena kedua bahan utama serta bahan pendukung lain yang digunakan tidak mampu menyumbang kadar lemak pada pembuatan food bar sebagai pangan darurat. Berdasarkan penelitian Suarni (2004), sorgum merupakan tumbuhan serealia yang memiliki kandungan lemak sebesar 3,50\% sedangkan rice bran memiliki kandungan lemak sebesar $20 \%$ yang kaya akan asam lemak tidak jenuh (70-90\%), khususnya asam oleat dan linoleate (Rao, 2000). Selain itu, pada umumnya setelah proses pengolahan bahan pangan akan terjadi kerusakan lemak. Tingkat kerusakannya sangat bervariasi tergantung pada suhu yang digunakan dan lamanya waktu proses pengolahan. Semakin tinggi suhu yang digunakan, maka semakin intens kerusakan lemak.

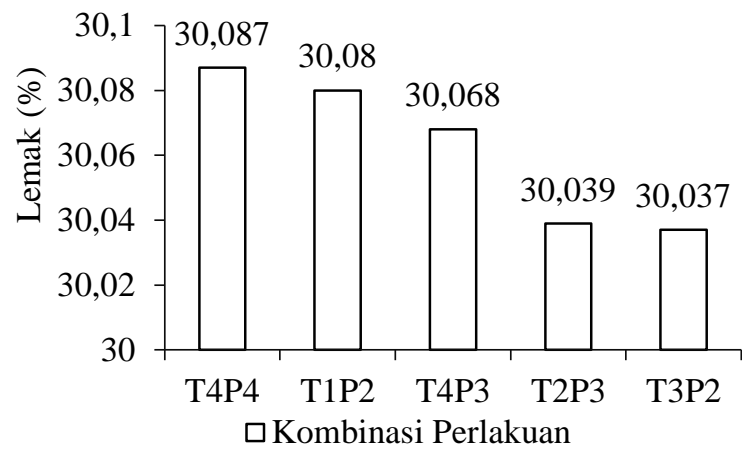

Gambar 2. Kadar lemak food bar dengan perlakuan berbasis tepung sorgum: stabilized rice bran 55\%:45\% (P1), 65\%:35\% (P2), $75 \%: 25 \% \quad(\mathrm{P} 3), \quad 85 \%: 15 \% \quad(\mathrm{P} 4)$ dan variasi suhu pemanggangan $115^{\circ} \mathrm{C}$ (T1), $120^{\circ} \mathrm{C}(\mathrm{T} 2), 125^{\circ} \mathrm{C}(\mathrm{T} 3), 130^{\circ} \mathrm{C}$ (T4)

\section{Karbohidrat Food Bar}

Karbohidrat merupakan sumber energi utama bagi tubuh manusia sehingga persentase pemenuhan kebutuhan energi yang berasal dari karbohidrat berada pada kisaran 55-65\% dari total kalori untuk orang tanpa gangguan metabolisme (Almatsier, 2004). Karbohidrat berperan dalam menentukan karakteristik bahan pangan seperti rasa, warna, dan tekstur (Winarno, 2008).

Kombinasi perlakuan suhu pemanggangan dan formulasi food bar (TP) tidak berpengaruh nyata terhadap kadar karbohidrat food bar yang dihasilkan. Data yang dihasilkan menunjukkan tidak ada perbedaan yang signifikan maka data tidak dilanjutkan dengan uji beda nyata menggunakan analisis Duncan's Mutliple 
Range Test (DMRT) pada taraf signifikan $\alpha$ $=0,05$.

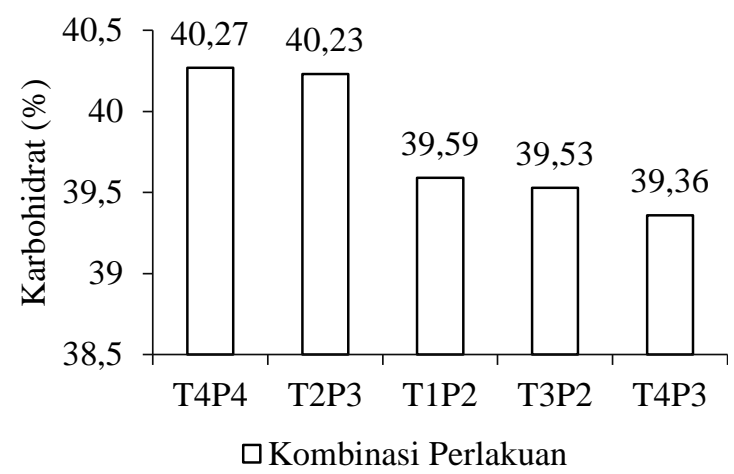

Gambar 3. Kadar karbohidrat food bar dengan perlakuan berbasis tepung sorgum: stabilized rice bran 55\%:45\% (P1), 65\%:35\% (P2), 75\%:25\% (P3), $85 \%: 15 \%$ (P4) dan variasi suhu pemanggangan $115^{\circ} \mathrm{C} \quad(\mathrm{T} 1), \quad 120^{\circ} \mathrm{C}$ (T2), $125^{\circ} \mathrm{C}(\mathrm{T} 3), 130^{\circ} \mathrm{C}(\mathrm{T} 4)$

Nilai kadar karbohidrat pada masingmasing sampel food bar menunjukkan nilai tertinggi yaitu T4P4 (proporsi tepung sorgum:stabilized rice bran 85:15\% dan suhu pemanggangan $130^{\circ} \mathrm{C}$ ) sebesar 40,27 $\%$ dan terendah pada T4P3 (proporsi tepung sorgum:stabilized rice bran 75:25\% dan suhu pemanggangan $125^{\circ} \mathrm{C}$ ) sebesar 39,36\% (Gambar 3). Kualitas food bar yang baik sebagai pangan darurat, menurut Zoumas (2002) karbohidrat yang harus dipenuhi yaitu 40-50\%. Hal ini menunjukkan kandungan karbohidrat yang terkandung dalam food bar dengan bahan utama tepung stabilized rice bran dan tepung sorgum sudah memenuhi standar. Nilai gizi sorgum cukup memadai sebagai bahan pangan, yaitu mengandung sekitar $83 \%$ karbohidrat, sedangkan kandungan zat gizi yang dimiliki rice bran yaitu 67,8$72,74 \%$ (Dodik, 2017). Proses pemanggangan membuat kadar karbohidrat yang ada pada food bar menjadi berubah bentuk. Proses pemanasan akan mengakibatkan terjadi leaching atau rusaknya molekul pati (Kurniawan et al., 2015).

\section{Karakteristik Fisik (Kekerasan/ Hardness) Food Bar}

Menurut Mahmudah (2017), nilai hardness menunjukkan besarnya gaya tekan yang diperlukan untuk deformasi produk. Semakin tinggi nilai kekerasan suatu produk menunjukkan produk tersebut memiliki kerenyahan yang rendah dan sebaliknya (Mahmudah, 2017). Tekstur pangan ditentukan oleh kadar air, kadar lemak, dan kandungan karbohidrat struktural seperti selulosa, pati, dan bahan pektin serta protein yang terkandung dalam suatu produk (Chen \& Stokes, 2012). Oleh karena itu kandungan dalam suatu bahan pangan memiliki peranan penting terhadap tekstur suatu produk (Gambar 4).

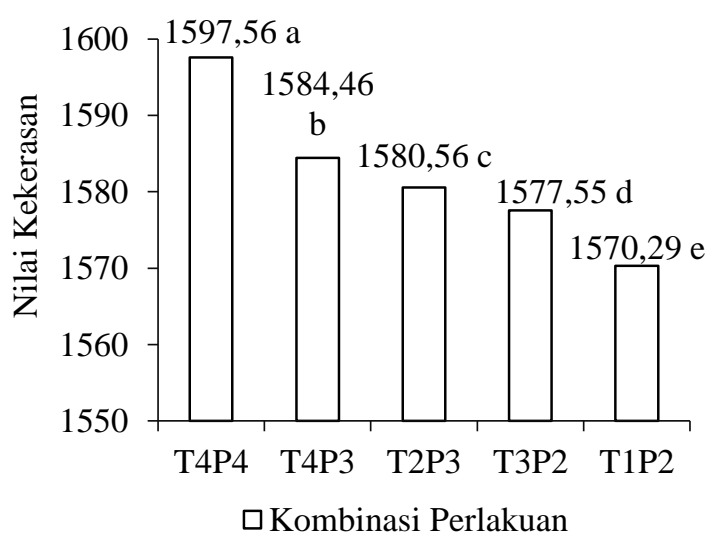

Gambar 4. Nilai kekerasan food bar dengan perlakuan berbasis tepung sorgum: stabilized rice bran 55\%:45\% (P1), 65\%:35\% (P2), 75\%:25\% (P3), $85 \%: 15 \%$ (P4) dan variasi suhu pemanggangan $115^{\circ} \mathrm{C}$ (T1), $120^{\circ} \mathrm{C}$ (T2), $125^{\circ} \mathrm{C}$ (T3), $130^{\circ} \mathrm{C}$ (T4)

Hasil analisis tingkat kekerasan pada food bar diperoleh nilai kekerasan tertinggi yaitu 1597,56 g force pada perlakuan T4P4, sedangkan nilai kekerasan terendah yaitu 1570,29 g force pada perlakuan T1P2. Semakin tinggi nilai tingkat kekerasan maka semakin keras pula tesktur dari food bar. Nilai kekerasan pada food bar diakibatkan oleh proses retrodegradasi pati dari kedua bahan baku yang digunakan yaitu tepung stabilized rice bran dan tepung 
sorgum. Retrodegradasi merupakan proses terbentuknya ikatan antara amilosa yang telah terdispersi ke dalam air. Semakin banyak amilosa yang terdispersi, semakin keras produk tersebut (Chandra, 2010).

Berdasarkan penelitian Ferawati (2009) pada pembuatan banana bars berbahan dasar tepung kedelai, terigu, singkong, dan pisang sebagai alternatif pangan darurat memiliki nilai kekerasan sebesar 1387,5 g force. Selain itu, pada Natalia (2010) yang meneliti produk food bar komersil yaitu fruit soybar memiliki nilai kekerasan berkisar $667 \mathrm{~g}$ force sampai $1292 \mathrm{~g}$ force. Walaupun nilai kekerasan yang dimiliki lebih tinggi dari penelitian Ferawati (2009) dan Natalia (2010), akan tetapi masih dapat diterima secara organoleptik. Hal ini menunjukkan bahwa nilai kekerasan (hardness) food bar sebagai pangan darurat dengan bahan utama tepung stabilized rice bran dan tepung sorgum sudah memiliki nilai kekerasan yang baik karena memiliki tekstur yang kokoh yang akan mempermudah dalam proses pendistribusian.

\section{KESIMPULAN}

Penggunaan suhu $120^{\circ} \mathrm{C}$ selama 6 menit sudah mampu memperbaiki kualitas rice bran. Rice bran yang dihasilkan berwarna kuning kecoklatan dan memiliki aroma rancid yang berkurang. Formulasi produk food bar terbaik yaitu food bar dengan rasio tepung sorgum:tepung stabilisasi rice bran sebanyak 85\%:15\% (P4) yang dipanggang pada suhu $130^{\circ} \mathrm{C}$ (T4). Formulasi ini menunjukkan nilai protein total $14,99 \%$; lemak $30,08 \%$; karbohidrat 40,27\% dan energi 246,01 kkal serta memiliki karakter fisik berupa nilai kekerasan sebesar 1597,56 g force.

\section{UCAPAN TERIMA KASIH}

Ucapan terima kasih ditujukan kepada PT. Indofood Sukses Makmur Tbk yang telah mendukung secara finansial terlaksananya penelitian ini dalam program Indofood Riset Nugraha 2019.

\section{DAFTAR PUSTAKA}

Agbaje, R., Hassan, C.Z., Arifin, N., dan Rahman, A.A. 2014. Sensory preference and mineral contents of cereal bars made from glutinous rice flakes and sunnah foods. IOSR Journal of Environmental Science, 8: 26-31.

Aini, N., Prihananto, V., Wijonarko, G., Sustriawan, B., Dinayati, M., and Aprianti, F. 2018. Formulation and characterization of emergency food based on instan corn flour supplemented by instan tempeh (or soybean) flour. International Food Research Journal, 25 (1): 287-292.

Ahza, A.B. 1988. Teknologi Ekstruksi. Institut Pertanian Bogor, Bogor.

Almatsier S. 2004. Prinsip Dasar Ilmu Gizi. PT Gramedia Pustaka Utama, Jakarta.

Anandito, R.B.K., Siswanti, S., Nurhartadi, E., dan Hapsari, R. 2016. Formulasi pangan darurat berbentuk food bars berbasis tepung millet putih (Panicum milliaceum L.) dan tepung kacang merah (Phaseolus vulgaris L.). Jurnal Agritech, 36 (1): 2329.

Astawan, M., Riyadi, H., dan Nurhayati, E. 2013. Perendaman asam askorbat dapat memperbaiki sifat fisik, kimia, sensori, dan umur simpan tepung bekatul fungsional. Pangan, 22 (1): 49-60.

BNPB. 2013. Indeks Risiko Bencana Indonesia. Direktorat Pengurangan Risiko Bencana Deputi Bidang Pencegahan dan Kesiapsiagaan, Sentul. ISBN: 978-60270256-0-8.

Budijanto, S., Andri, Y.I., Faridah, D.N., dan Noviasari, S. 2017. Karakterisasi kimia dan efek hipoglikemik beras analog berbahan dasar jagung, sorgum dan sagu aren. Agritech, 37 (4): 402-409.

Chandra, F. 2010. "Formulasi Snack Bar Tinggi Serat Berbasis Tepung Sorgum, Tepung Maizena dan Tepung Ampas Tahu”. Skripsi. Institut Pertanian Bogor, Bogor. 
Chen, J., dan Stokes, J. 2012. Rheology and tribology: two distinctive regines of food texture sensation. Journal Food Science and Technology, 25(1): 4-12.

Dahir M., Zhu K., Guo X., Aboshora W., and Peng W. 2015. Possibility to utilize sorghum flour in a modern bread making industry. Journal of Academia and Industrial Research, 4 (4): 128-135.

da Silva, E.P., Siqueira, H.H., do Lago, R.C., Rosell, C.M., and Vilas Boas, E.V. de B. 2014. Developing fruit-based nutritious snack bars. Journal of the Science of Food and Agriculture, 94 (1): 52-56.

Dodik, L., Retno D.N., dan Kurniati, I. 2017. Karakteristik kandungan gizi bekatul pada berbagai varietas beras di surakarta. The $6^{\text {th }}$ University Research Colloquium. Malang. Universitas Muhammadiyah Magelang.

Ekafitri, R., dan Isworo, R. 2014. Pemanfaatan kacang-kacangan sebagai bahan baku sumber protein untuk pangan darurat. Pangan, 23 (2): 134-145.

Fauzan, F. 2005. "Formulasi Flakes Komposit dari Tepung Talas, Tepung Tempe dan Tapioka". Skripsi. Institut Pertanian Bogor, Bogor.

Ferawati. 2009. "Formulasi dan Pembuatan Banana Bars Berbahan Dasar Tepung Kedelai, Terigu, Singkong dan Pisang sebagai Alternatif Pangan Darurat". Skripsi. Institut Pertanian Bogor, Bogor.

Huang S.C., Shiau C.Y., Liu T.E., Chu C.L., and Hwang, D.F. 2005. Effects of rice bran on sensory and physico-chemical properties of emulsified pork meatballs. Meat Science, 70 (4): 613-619.

Isdamayani, L., dan Panunggal, B. 2015. "Kandungan Flavonoid, Total Fenol, dan Antioksidan Snack Bar Sorgum Sebagai Alternatif Makanan Selingan Penderita Diabetes Mellitus Tipe 2". Doctoral Dissertation. Diponegoro University, Semarang.

Kusharto, C.M. 2006. Serat makanan dan peranannya bagi kesehatan. Jurnal Gizi dan Pangan, 1 (2): 45-54.
Kusumastuty, I., Fandianty, L., dan Julia, A.R. 2015. Formulasi food bar tepung bekatul dan tepung jagung sebagai pangan darurat. Indonesian Journal of Human Nutrition, 2 (2): 68-75.

Liu, Y.Q., Strappe, P., Shang, W. T., and Zhou, Z.K. 2017. Functional peptides derived from rice bran proteins. Journal Food Science and Nutrition, 8: 1-8.

Mahmudah, N.A., Amanto, B.S. dan Widowati, E. 2017. Karakteristik fisik, kimia, dan sensoris flakes pisang kepok samarinda (Musa paradisiaca Balbisiana) dengan substitusi pati garut. Jurnal Teknologi Hasil Pertanian, 10 (1): 32-40.

Mulyadi, A.F., Wijana, S., Dewi, I.A., dan Putri, W.I. 2014. Karakteristik organoleptik produk mie kering ubi jalar kuning (Ipomoea batatas) (Kajian penambahan telur dan CMC). Jurnal Teknologi Pertanian, 15 (1): 25-36.

Natalia, D. 2010. "Sifat Fisikokimia dan Indeks Glikemik Berbagai Produk Snackbar". Skripsi. Institut Pertanian Bogor, Bogor.

Rafe, A., dan Sadeghian, A. 2017. Stabilization of Tarom and Domesiah cultivars rice bran: Physicochemical, functional and nutritional properties. Journal of Cereal Science, 74: 64-71.

Rao B.S.N. 2000. Nutritive value of rice bran. Nutrition Foundation of India, 5-8.

Rhodes, D.H., Hoffmann Jr, L., Rooney, W.L., Ramu, P., Morris, G.P. and Kresovich, S. 2014. Genome-wide association study of grain polyphenol concentrations in global sorghum (Sorghum bicolor (L.) Moench) germplasm. Journal of Agricultural and Food Chemistry, 62 (45): 10916-10927.

Sari, D.Y.E., Angkasa, D., dan Swamilaksita, P.D. 2017. Daya terima dan nilai gizi snack bar modifikasi sayur dan buah untuk remaja putri. Jurnal Gizi, 6 (1): 111.

Sharma, R., Srivastava, T., and Saxena DC. 2015. Studies on rice bran and its benefits-a review. International Journal of Engineering Research and Applications, 5 (5): 107-112. 
Suarni. 2004. Evaluasi sifat fisik dan kandungan kimia biji sorgum setelah penyosohan. Jurnal Stigma, 12 (1): 8891.

Sudarmadji, S., Bambang, H., dan Suhardi. 2007. Analisa Bahan Makanan dan Pertanian. Liberty, Yogyakarta

Suhardjo, L.J., Harper, Deaton, B.J., dan Driskel, J. A. 2006. Pangan, Gizi dan Pertanian. Penerbit Universitas Indonesia, Jakarta.

Sumantri, A. 2013. Kesehatan Lingkungan. Prenada Media Group, Depok.

Susanto, D. 2011. "Potensi Bekatul sebagai Sumber Antioksidan dalam Produk Selai Kacang”. Skripsi. Studi Ilmu Gizi, Fakultas Kedokteran, Universitas Diponogoro, Semarang.

Winarno, F.G. 1991. Kimia Pangan dan Gizi. Gramedia Pustaka Utama, Jakarta.

Winarno FG. 2008. Kimia Pangan dan Gizi. M Brio Press, Jakarta.

Wulandari, M., dan Erma, H. 2010. Pengaruh penambahan bekatul terhadap kadar protein dan sifat organoleptik biskuit. Jurnal Pangan dan Gizi, 1 (2): 55-62.

Trisnawati, C.Y., Srianta, I., Nugerahani, I., dan Marsono, Y. 2019. Incorporating Monascus-fermented durian seeds and rice bran into bread: Study on the bread physicochemical and sensory properties. Food Research, 3 (3): 280-284.

Zoumas. 2002. High-Energy, Nutrien-Dense Emergency Relief Food Product. Food and Nutrition Board, Institute of Medicine. 